\title{
Guest Editors: A Potpourri Of Innovative Applications Of LEGO® In Learning, Teaching And Development
}

\author{
Prof Alison James
}

\section{University of Winchester, United Kingdom}

\section{Dr Chrissi Nerantzi}

\section{Manchester Metropolitan University, United Kingdom}

This special issue of the International Journal for Management and Applied Research is dedicated to $\mathrm{LEGO}{ }^{\circledR}$ and a method of using it which has been established for almost 20 years and which is well known in business and management circles. While associated with, and widely used for, the development of executive and strategic thinking to facilitate change, LEGO® SERIOUS PLAY® is increasingly being used in higher education to explore complex issues and questions and engage learners and academic staff in more hands-on approaches to learning and development. As this collection of papers reveals, its techniques are being widely used and adapted in diverse contexts; its effects and outcomes are also being considered through a range of lenses, including the critically reflective and the research-based. The photographs included bring some of the contributions alive and provide valuable visual insights.

This issue reinforces for newcomers to LEGO SERIOUS PLAY key aspects of its purpose and application. As you read through the different contributions you will notice the dense theoretical underpinnings present in most, if not all, papers. Some sources are repeatedly cited, while the inclusion of others indicates the extent of literature on the method now available. Theoretical considerations are also enriched across the papers by an intermingling of the subject-related and pedagogic, as well as those associated with LEGO SERIOUS PLAY and LEGO more widely.

Our contributors are located in different countries, disciplines and professional areas, and as a result you will find competing views, perspectives and experiences alongside commonalities of belief and position. You will also find tensions between the serious and the playful, constraint and freedom, recurring in the many motifs. There is both unity and diversity of different theoretical and practical domains, including considerations of: 
- Co-design and play

- Acting

- Innovation education

- Leadership lessons for graduate students

- Aspects of the doctoral journey

- Promoting critical reflection in medical education

- Nanotechnology

- Career counselling

- Academic writing and referencing

- Storytelling

and more.

Authors write as participants in and as practitioners/researchers of LEGO SERIOUS PLAY. Several of them note aspects of the method's etiquette; the need to respect confidentiality and not share stories/identify individual builders; several share annotated illustrations which reveal how models built can influence work after workshops and further LEGO SERIOUS PLAY activities through the recollection of insights garnered. There are multiple examples of student or participant feedback which have common commentaries around surprise, enjoyment, flow, openness, engagement, enriched learning and other benefits.

The applications and principles of the method in its pure form are clearly stated, while authors also show how inventive they can be in taking the tenet of the LEGO SERIOUS PLAY system and combining it with other techniques, approaches, tools and materials. A similar combination can be seen in the structure of papers, some which combine traditional research methods and language with the pragmatic accounts of LEGO SERIOUS PLAY and its situating literature. 'A few papers are at the reflection end of the authorship spectrum with some having a rather deep ruminating narrative, while others are geared towards the research Contributors give examples of how an introductory LEGO SERIOUS PLAY activity can be modified away from the general (build a model of your identity) to the more specific (what is your superpower?). Such an example supports the broader point made that in uncertain times where existing solutions no longer seem to suffice then being inventive or unconventional is the way forward. In among the LEGO SUPER PLAY contributions, one author confesses to not doing LEGO SERIOUS PLAY at all, and yet evidences a highly engaging and impactful approach to enabling students to understand the complex functioning and construction of an ophthalmic instrument through playful, competitive construction.

Some contributions are complex considerations of a topic, such as the integration of strengths-based counselling, coaching, LEGO SERIOUS PLAY and the Six Brick approach to enabling students to explore their career journeys. There are touchpoints in unrelated papers which connect with each other, for example the consideration of coaching in this paper also links to the consideration of coaching in a phenomenographic study of doctoral students and doctoral researchers' development

International Journal of Management and Applied Research, 2018, Vol. 5, No. 4 
using coaching and LEGO SERIOUS PLAY techniques. Emotional labour appears in this paper and connections to another about emotion work during the $\mathrm{PhD}$.

There are powerful references made to the world of business, management and innovation as well as to the strains of operating in the higher education sector today; the papers and the models both expressing the challenges that we face living, educating and operating in these worlds at present.

While several papers are interested in metacognitive or experiential aspects of LEGO SERIOUS PLAY activity, others emphasise how it can support engagement with learning content and concepts. For example, reasons why students want to study medicine, or how the use of LEGO-based activities to consolidate understand of Stanislawskian principles of acting can inform subsequent essay writing.

As you can see, even a relatively small selection of papers on LEGO SERIOUS PLAY generates a richness of perspectives and practices that we feel sure will resonate in some ways with your own. We hope you will enjoy reading the different contributions and that they will inspire your own adoption and adaption of the method in your contexts.

\section{Bibliography}

1. Frick E., Tardini S. and Cantoni L. (2014), "LEGO SERIOUS PLAY Applications to enhance creativity in participatory design”, In: Reisman, F. K. (Eds), Creativity in Business, KIE Conference Books, pp.200-210.

2. Gauntlett, D (2013), David Gauntlett, [Online] Available from: http://www.davidgauntlett.com [Accessed on 1 November 2018].

3. James, A. (2014), "Learning in three dimensions: using Lego SERIOUS PLAY for creative and critical reflection across time and space", in: Layne, P.C. and Lake, P. (Eds.) Global Innovation of Teaching and Learning in Higher Education: Transgressing Boundaries, Professional Learning and Development in Schools and Higher Education, Vol. 11. Cham: Springer, pp. 275-294. https://doi.org/10.1007/978-3-319-10482-9_17

4. James, A. (2015), Innovative pedagogies series: Innovating in the Creative Arts with LEGO. York: Higher Education Academy. [Online] Available from: https://www.heacademy.ac.uk/system/files/alison_james_final.pdf [Accessed on 1 November 2018].

5. James, A. (2016), "Play and 3D enquiry for stimulating creative learning", in: Watts, L. and Blessinger, P. (Eds) Creative Learning: International Perspectives and Approaches in Higher Education, New York: Routledge.

6. James, A. (2018, "Case study 28: Transition as metaphor: how building with LEGO® helps students navigate teamworking for an external client", in: Matheson., R, Tangney., S, Sutcliffe., and Poole, N. (Eds), Transition in, through and out of higher education, New York: Routledge.

International Journal of Management and Applied Research, 2018, Vol. 5, No. 4 
7. James, A. and Brookfield S, (2016), "The Serious Use of Play and Metaphor", in: Wang, V. (ed.), Adult Education in the Digital Age, Hershey: IGI Global, pp. 118133.

8. James, A. and Brookfield, S. D. (2014), Engaging imagination: Helping students become creative and reflective thinkers, San Francisco: Jossey Bass.

9. Kristiansen, P. and Rasmussen, R. (2014), Building a better business using the LEGO® SERIOUS PLAY® method, Hoboken, New Jersey: Wiley.

10. Nerantzi, C., and Despard, C. (2014) "Do Lego® Models Aid Reflection in Learning and Teaching Practice?", Journal of Perspectives in Applied Academic Practice, Vol. 2 No. 2, pp. 31-36. https://doi.org/10.14297/jpaap.v2i2.81

11. Nerantzi, C. and McCusker, S. (2014), "A taster of the LEGO® SERIOUS PLAY® Method for Higher Education", OER14 Building Communities of Open Practice, 28-29 April 2014, Newcastle: Centre for Life.

12. Nerantzi, C., Moravej, H., Johnson, F., (2015), "Play Brings Openness", Journal of Perspectives in Applied Academic Practice, Vol. 3, No. 2, pp. 82-91. https://doi.org/10.14297/jpaap.v3i2.141

13. Nolan, S. (2010), "Physical Metaphorical Modelling with LEGO as a Technology for Collaborative Personalised Learning”, In. J. O'Donoghue (ed.) Technologysupported Environments for Personalised Learning: Methods and Case Studies. New York: Hersey, Information Science Reference, pp. 364-385.

14. Serious Play Pro (2018), SeriouslayPro.com links professional facilitators using LEGO ${ }^{\circledR}$ SERIOUS PLAY® methodology, [Online] Available from: http://seriousplaypro.com/ [Accessed on 1 December 2018].

15. The LEGO Group (2010). Open-source/<Introduction to LEGO® SERIOUS PLAY®, [Online] Available from: http://seriousplaypro.com/about/open-source/ [Accessed 6 November 2018].

\section{Upcoming books}

1. James, A. (forthcoming), LEGO ${ }^{\circledR}$ and $L E G O ®$ SERIOUS PLAY®, information at: https://engagingimagination.com/lego-and-lego-serious-play-2/

2. James, A. and Nerantzi C. (in press, 2019), The Power of Play in Higher Education: Creativity in Tertiary Learning. Palgrave MacMillan; click here to access the flyer: https://www.springer.com/br/product-marketing$\underline{\text { tool/flyer/9783319957791 }}$

3. Nerantzi, C. and James, A. (forthcoming), LEGO® for university learning: inspiring academic practice in higher education, information at https://chrissinerantzi.wordpress.com/2017/12/09/almost-there-now-new-ccbooklet-in-preparation-legoseriousplay-lsphe-opened-open/

International Journal of Management and Applied Research, 2018, Vol. 5, No. 4 